\title{
Spotkanie po ASCO 2015
}

W dniach 26-27 czerwca 2015 r. w Gdańsku odbyło się "Spotkanie po ASCO".

Motto Kongresu ASCO 2015 - „Illumination and Innovation: Transforming Data into Learning" miało uświadomić uczestnikom, że najważniejsza jest możliwość przeniesienia najnowszych osiągnięć na grunt codziennej praktyki lekarskiej. Podkreślono, że corocznie prezentowanych jest mnóstwo nowych doniesień, jednak kluczową kwestią jest ich przydatność dla lekarzy i chorych. Szybko rosnąca ilość informacji, szczególnie w zakresie nauk podstawowych, bywa przytłaczająca, a nie zawsze znajduje zastosowanie praktyczne.

\section{Biologia nowotworów i nowe leki}

Piotr Wysocki

Większość doniesień dotyczyło immunologii nowotworów. Modyfikacja czynności układu immunologicznego (immunosupresja, immunorekonstrukcja, immunostymulacja) jest w onkologii coraz szerzej stosowana, nadal jednak nie wiadomo, jakie są czynniki predykcyjne skuteczności i oporności. Trwają intensywne badania leków ukierunkowanych na receptor PD-1 (białko zaprogramowanej śmierci komórki typu 1 - programmed cell death protein 1; receptor supresyjny, obecny na powierzchni aktywowanych limfocytów T) i jeden z jego ligandów - PD-L1. W ostatnich latach kilka takich leków zostało zarejestrowanych, a kolejne są w różnych fazach badań klinicznych. $W$ badanach in vitro wykazano, że awelumab, przeciwciało anty PD-L1, łącząc się z białkiem PG-L1 na powierzchni komórek nowotworowych może dodatkowo indukować reakcję cytotoksyczności komórkowej zależnej od przeciwciał (Antibody Dependent Cellular Cytotoxicity, ADCC), prowadzącą do lizy komórek (abstr. 3038). Zachęcające są próby kojarzenia leków anty-PD-L1 z inhibitorami BRAF i/lub MEK (abstr. 3003). Teoria nadzoru immunologicznego Burneta i Thomasa wyjaśnia mechanizm kontroli komórek nowotworowych przez układ immunologiczny. Zakłada ona, że komórki zmienione nowotworowo pojawiają się w organizmie znacznie częściej niż nowotwory ujawnione klinicznie i są stale kontrolowane przez odpowiednie mechanizmy odpornościowe. Układ odpornościowy szybko wykrywa i niszczy takie nietypowe komórki, zanim staną się zdolne do ucieczki spod nadzoru immunologicznego. Upośledzenie sprawności tej ochrony prowadzi do proliferacji komórek nowotworowych. Obecnie przedmiotem licznych badań jest znaczenie nacieków limfocytarnych w różnych nowotworach. Porównanie materiałów tkankowych pochodzących z guza pierwotnego i przerzutów raka potrójnie ujemnego i HER2-dodatniego wykazało wyraźne zmniejszenie populacji limfocytów naciekających ogniska przerzutowe w porównaniu z ogniskiem pierwotnym, co potwierdza mniejszą immunogenność przerzutów i potencjalne znaczenie mechanizmów ucieczki spod nadzoru immunologicznego w procesie uogólnienia nowotworu (abstr. 11021). Dodatkowo zaobserwowano szczególnie złe rokowanie u chorych z najmniejszymi naciekami limfocytarnymi w przerzutach.

\section{Epidemiologia i profilaktyka}

Renata Duchnowska

W ostatnich latach pojawiło się wiele doniesień o związku aktywności fizycznej z występowaniem i wynikami leczenia nowotworów. Około 80\% tych doniesień dotyczy wczesnego raka piersi. Metaanaliza 38 niezależnych prospektywnych badań, w których oceniono losy ponad 100 tys. chorych na raka piersi, wykazała, że zwiększona aktywność fizyczna jest związana z niższym ryzykiem zachorowania, aczkolwiek stosowanie hormonalnej terapii zastępczej znosi ten ochronny efekt (abstr. 1561). Zaobserwowano także korzystny wpływ zwiększonej i systematycznej aktywności fizycznej (co najmniej 4 godziny ćwiczeń o umiarkowanej intensywności tygodniowo) na wydłużenie czasu całkowitego przeżycia u chorych na potrójnie ujemnego raka piersi (abstr. 1507). Nadal poszukuje się skutecznych sposobów profilaktyki farmakologicznej (abstr. 1506 - obniżenie umieralności z powodu nowotworu u chorych po menopauzie regularnie stosujących statyny; abstr. 3504 - wydłużenie czasu przeżycia u chorych na raka jelita grubego stosujących kwas acetylosalicylowy; abstr. 3503 — korzystniejsze wskaźniki przeżycia wolnego od progresji i przeżycia całkowitego u chorych na raka jelita 
grubego, u których stwierdzono wysokie stężenie witaminy D). Konieczne są dalsze badania dla określenia precyzyjnych zaleceń. Dotyczy to $\mathrm{m}$. in. zdefiniowania grup wysokiego ryzyka czy zmniejszenia wpływu niepożądanych objawów stosowanych preparatów, np. aspiryny czy tamoksyfenu. W badaniu NSAPB zaobserwowano, że nasilone objawy wazomotoryczne (uderzenie gorąca, nocne poty) w trakcie stosowania tamoksyfenu w profilaktyce raka piersi występują częściej u osób otyłych, co prowadzi do nieregularnego stosowania leku w tej grupie (abstr. 1501).

\section{Chłoniaki}

Renata Zaucha

Dodanie rytuksymabu do chemioterapii znamiennie poprawiło wyniki leczenia chłoniaków, jednak w przypadku niepowodzenia czy oporności na rytuksymab dalsze leczenie jest mało skuteczne. Zarejestrowana w 2008 bendamustyna pozwala wprawdzie uzyskać wysoki odsetek odpowiedzi (ORR 70-75\%), ale mediana czasu wolnego od progresji wynosi zaledwie 7-9 miesięcy. Nowe przeciwciała skierowane na antygen CD20 (abstr. 8501 - ublituksymab, abstr. LBA 8502 - obinutuzumab), dzięki inżynieryjnej modyfikacji, mają większą siłę wiązania $z$ antygenem lub wyzwalania reakcji ADCC. Innym nowym celem przeciwciał jest antygen CD19 (abstr. 8500 - MOR208, przeciwciało wiążące się zantygenem CD19. Większośćtych leków jest obecniew llub II fazie badań. Prospektywne badanie III fazy wykazało, że skojarzenie obinutuzumabu z bendamustyną w grupie chorych z opornością na rytuksymab pozwala uzyskać znamienną poprawę mediany czasu wolnego od progresji w porównaniu z wyłączną bendamustyną (abstr. LBA 8502), jednak koszt leczenia skojarzonego był niemal 3-krotnie wyższy.

\section{Nowotwory głowy i szyi}

Monika Rucińska

W sesji plenarnej Kongresu ASCO 2014 zaprezentowano badanie III fazy oceniające skuteczność elektywnego usuwania szyjnych węzłów chłonnych we wczesnym raku jamy ustnej, z cechą cNO (abstr. LBA 3). Wykazano, że postępowanie takie poprawia odsetek 3-letnich przeżyć całkowitych i wolnych od choroby, a także zmniejsza ryzyko zgonu i wznowy w porównaniu z limfadenektomią podejmowaną dopiero w przypadku wznowy. W ośrodkach niewykonujących rutynowo USG $w$ ramach badań kontrolnych elektywna limfadenektomia wydaje się zatem postępowaniem z wyboru mimo powikłań, jakie powoduje.

Radiochemioterapia pozostaje standardem leczenia miejscowo zaawansowanych raków głowy i szyi. Przeciwciała anty-EGFR mogą być rozważane u chorych z przeciw- wskazaniami do leczenia cisplatyną, ale nie są od niej skuteczniejsze. Panitumumab dołączony do radiochemioterapii nie poprawia wyników leczenia ani jakości życia chorych (abstr. 6000, 6053).

Pembrolizumab, przeciwciało blokujące receptor PD-1, zastosowany w leczeniu nawrotowych lub przerzutowych płaskonabłonkowych raków regionu głowy i szyi pozwala na uzyskanie $25 \%$ odpowiedzi zarówno u chorych na raka HPV-dodatniego, jak i -ujemnego, przy dobrej tolerancji (abstr. 6008).

Przetrwałe DNA wirusa HPV16 po leczeniu HPV(+) raków ustnej części gardła związane jest z wystąpieniem szybszego nawrotu choroby i z gorszym rokowaniem (abstr. 6005).

\section{Rak płuca \\ Rafał Dziadziuszko}

Mutacja somatyczna T790M w eksonie 20. genu EGFR, występująca u chorych na niedrobnokomórkowgo raka płuca (NDRP), związana jest z opornością na inhibitory kinazy tyrozynowej (IKT). W chwili rozpoznania jest ona obecna u ok. $1 \%$ chorych na NDRP, natomiast u chorych z opornością na IKT występuje w 50\%. Być może w trakcie terapii dochodzi do selekcji komórek z mutacją T790M, które stają się $w$ ten sposób dominującym klonem. Leczenie rokiletynibem (inhibitorem EGFR trzeciej generacji) jest związane z długotrwałymi odpowiedziami i dobrą tolerancją u chorych na NDRP z mutacją T790M stwierdzoną podczas progresji po uprzednim leczeniu IKT (abstr. 8001). Wysoką aktywność wykazują także inne selektywne inhibitory EGFR trzeciej generacji, aczkolwiek są to jeszcze badania wczesnych faz (abstr. 8000, 8013).

Modulatory odpowiedzi immunologicznej stosowane w kolejnych liniach leczenia NDRP wykazują wyższą skuteczność niż chemioterapia. Leczenie niwolumabem chorych na płaskonabłonkowego raka płuca z progresją po chemioterapii opartej o pochodne platyny pozwala uzyskać znamiennie dłuższy czas przeżycia, czas przeżycia wolnego od progresji oraz wyższy odsetek odpowiedzi w porównaniu z leczeniem docetakselem (abstr. 8009). Zależność efektu niwolumabu od nasilenia ekspresji PD-L1 w ocenie immunohistochemicznej wycinków z guza pozostaje przedmiotem kontrowersji (abstr. 8009 i LBA 109). Analiza podgrup sugeruje mniejszą skuteczność niwolumabu w rakach z mutacją EGFR, co być może jest efektem mniejszej immunogenności takich raków (LBA 109).

Wstępne dane wskazują na długotrwały efekt przeciwnowotworowy i akceptowalny profil toksyczności dla skojarzenia pembrolizumabu i ipilimumabu u chorych na NDRP po wcześniejszym leczeniu systemowym (abstr. 8011, badanie I fazy). Skuteczność atezolizumabu (MPDL3280A) w II linii leczenia chorych na NDRP z wysoką ekspresją PD-L1 jest wyższa w porównaniu z docetakselem (abstr. 8010). 
PD-L1 możebyćzatem predykcyjnym biomarkeremzwiązanym z wrażliwością na leczenie modulatorami odpowiedzi immunologicznej, jednak wymaga to standaryzacji oceny immunohistochemicznej PD-L1 (metoda barwienia, punkt odcięcia).

Intensywnie badane są nowe cele molekularne oraz leki na nieukierunkowane (mutacje MET — abstr. 8021, mutacje NF1 - abstr. 8022, ROS1 - abstr. 8018, RET-8007). Skojarzone leczenie dabrafenibem i trametynibem wykazało zadawalającą aktywność przeciwnowotworową i korzystny profil działań niepożądanych tych leków u chorych na uogólnionego NDRP z mutacją BRAF V600E (abstr. 8006). Alektynib, wysoce selektywny inhibitor ALK, wykazał wysoką aktywność i dobrą tolerancję u ALK-dodatnich chorych na NDRP, u których doszło do progresji po leczeniu kryzotynibem (abstr. 8008).

Po wielu latach braku postępu w leczeniu drobnokomórkowego raka płuca (DRP) pojawiły się doniesienia o korzystnym działaniu modulatorów odpowiedzi immunologicznej. Pembrolizumab był dobrze tolerowany i wykazał obiecującą aktywność przeciwnowotworową u chorych na DRP z ekspresją PD-L1 (abstr. 7502). Niwolumab w monoterapii lub w połączeniu z ipilimumabem wykazał aktywność i zadawalający profil bezpieczeństwa u chorych na DRP z progresją po wcześniejszej chemioterapii (abstr. 7503).

\section{Nowotwory OUN}

Monika Rucińska

W sesji plenarnej przedstawiono wieloośrodkowe badanie III fazy oceniające celowość napromieniania całego mózgu (WBRT) w uzupełnieniu radiochirurgii (SRS) jako podstawowej metody leczenia ograniczonych (1-3) przerzutów w mózgu (abstr. LBA 4). Wykazano, żeWBRT znamiennie zmniejsza ryzyko miejscowej progresji, ale kosztem pogorszenia zdolności poznawczych oraz ogólnej jakości życia w ciągu pierwszych 3 miesięcy po leczeniu, i nie ma wpływu na całkowite przeżycie.

Standardowym leczeniem glejaka wielopostaciowego mózgu pozostaje skojarzenie radioterapii z temozolomidem, jednak wyniki leczenia są złe. Dasatynib, inhibitor kinaz rodziny Src, dodany do standardowej radioterapii z temozolomidem nie poprawia wyników (abstr. 2013), natomiast dołączony do bewacyzumabu w leczeniu chorych z nawrotem poprawia nieznamiennie medianę czasu trwania odpowiedzi, jednak bez wpływu na całkowite przeżycie.

\section{Nowotwory przewodu pokarmowego}

Marzena Wełnicka-Jaśkiewicz

Pembrolizumab w leczeniu chorych na raka jelita grubego pozwala na uzyskanie wysokiego odsetka obiektywnych odpowiedzi, ale tylko w przypadku raków z zaburzeniami systemów naprawy błędnie sparowanych podczas replikacji zasad azotowych (mismatch repair, MMR) (abstr. LBA 100).

$W$ retrospektywnym badaniu u chorych na raka wątrobowokomórkowego związanego z zakażeniem HBV lub HCV potwierdzono wcześniejsze doniesienia, wskazujące, że zakażeniu HBV znamiennie częściej towarzyszą niekorzystne czynniki histokliniczne (abstr. 4011). W tej podgrupie krótszy jest także czas do progresji i czas całkowitego przeżycia, a także znamiennie gorsza jest odpowiedź na leczenie sorafenibem.

Rak dróg żółciowych należy w Europie do nowotworów występujących rzadko, natomiast w krajach Dalekiego Wschodu nowotwór ten stanowi istotny problem kliniczny, a w Stanach Zjednoczonych notuje się wzrost zachorowalności. Zwykle nowotwór ten jest rozpoznawany w zaawansowanych stadiach i charakteryzuje się opornością na chemioterapię. Kompleksowe profilowanie genetyczne wykazało, że 2/3 chorych jest nosicielami zaburzeń genetycznych, stanowiących potencjalny cel terapeutyczny (abstr. 4009).

Selektywna wewnętrzna radioterapia (selective internal radiation therapy, SIRT), zwana także radioembolizacją, jest stosowana w leczeniu raka wątrobowokomórkowego oraz przerzutów do wątroby. W jednym z doniesień SIRT dołączona do chemioterapii FOLFOX u chorych na rozsianego raka jelita grubego $\mathrm{w}$ grupie $z$ wyłącznymi przerzutami w wątrobie okazała się skuteczniejsza od wyłącznej chemioterapii, przy akceptowalnej toksyczności (abstr. 3502). W odniesieniu do wszystkich lokalizacji przerzutów nie odnotowano jednak wydłużenia czasu wolnego od progresji.

\section{Nowotwory ginekologiczne}

Radosław Mądry

Większość prezentowanych badań dotyczyła inhibitorów PARP oraz hamowania angiogenezy. Nowe inhibitory PARP są obecnie we wczesnych fazach badań, a właściwa identyfikacja chorych mogących odnieść korzyść z takiego leczenia pozostaje dużym wyzwaniem (abstr. 5507 — weliparyb, abstr. 5508 - rukaparyb).

Badanie TRINOVA-1, opublikowane w 2014 roku, wykazało, że trebananib, inhibitor połączenia angiopoetyny 1 i 2 z receptorem Tie2, dołączony do paklitakselu nie wydłuża czasu przeżycia u chorych na nawrotowego raka jajnika. W dodatkowej analizie wyników obejmującej podgrupę chorych z wodobrzuszem wykazano obecnie znamienne wydłużenie czasu całkowitego przeżycia oraz mediany czasu do kolejnej progresji pod wpływem stosowanego leczenia w porównaniu z wyłączną chemioterapią (abstr. 5503). Częstość występowania objawów ubocznych w stopniu 3. i 4. była podobna, jednak w grupie otrzymującej lek badany 
częściej dochodziło do wcześniejszego zakończenia leczenia z powodu toksyczności.

Bewacyzumab dodany do paklitakselu i karboplatyny w leczeniu zaawansowanego lub nawrotowego raka endometrium wydłuża znamiennie medianę czasu wolego od progresji w porównaniu z wyłączną chemioterapią (abstr. 5502). Dane te pochodzą jednak z badania II fazy (MITO-END-2) i wymagają potwierdzenia.

\section{Czerniaki i mięsaki}

Piotr Rutkowski

Najważniejsze kierunki badań w czerniakach dotyczą nieswoistej immunoterapii, szczególnie leczenia ukierunkowanego na receptor śmierci PD1 i jego ligandy, a także inhibitorów kinaz BRAF i MEK, które są głównymi punktami mutacji w czerniakach. Naturalną konsekwencją zastosowania inhibitorów kinazy BRAF jest reaktywacja zablokowanego lekiem szlaku kinazy MAP, skutkująca opornością na leczenie. Uzasadnia to próby kojarzenia inhibitorów BRAF oraz inhibitorów kolejnej kinazy tego szlaku - MEK.

W badaniu III fazy porównującym skuteczność kombinacji dabrafenibu i trametynibu monoterapią dabrafenibem u chorych na zaawansowane czerniaki z obecnością mutacji BRAFV600 stwierdzono znamienne wydłużenie czasu przeżycia pod wpływem terapii skojarzonej (abstr. 102). Przewagę kombinacji w porównaniu z monoterapią odnotowano także $\mathrm{w}$ odniesieniu do skojarzenia wemurafenibu z kobimetynibem (abstr. 9006). Zaktualizowane wyniki badania coBRIM wykazały, że leczenie skojarzone w porównaniu z wemurafenibem z placebo istotnie wydłuża czas wolny od progresji. Kolejna kombinacja - enkorafenib i binimetynib - jest na etapie badań wczesnych faz, ale wyniki są obiecujące (abstr. 9007). W odniesieniu do immunoterapii skojarzenie ipilimumabu (anty CTLA-4) z niwolumabem (anty PD-1) w porównaniu z monoterapią każdym z leków jest aktywniejsze niż monoterapia każdym z leków i związane jest z wydłużeniem czasu przeżycia wolnego od progresji (abstr. LBA 1). Poważnym ograniczeniem w stosowaniu terapii skojarzonych pozostają jednak ich bardzo wysokie koszty.

Pembrolizumab wykazuje aktywność u chorych na czerniaka z przerzutami do mózgu (abstr. 9009) oraz na czerniaka gałki ocznej (abstr. 9010). Przedmiotem przyszłych badań będzie zapewne kojarzenie wymienionych nowych terapii systemowych $z$ radioterapią, zastosowanie ich w uzupełniającym leczeniu, a także identyfikowanie biomarkerów odpowiedzi na leczenie.

Potwierdzono, że chorzy na nowotwory podścieliskowe przewodu pokarmowego (GIST) otrzymujący imatynib przez 3 lata po operacji mają dłuższe przeżycie wolne od nawrotu choroby i dłuższe przeżycie całkowite niż otrzymujący imatynib przez rok (abstr. 10505). Erybulina i trabektydyna zastosowane w leczeniu kolejnej linii chorych na mięsaki typu L (liposarcoma i leiomyosarcoma) są skuteczniejsze od dakarbazyny stosowanej w monoterapii (abstr. LBA 10502 i 10503).

\section{Leczenie wspomagające}

Renata Zaucha

Utrata masy kostnej jest u chorych na nowotwory częstym zjawiskiem i stanowi poważny problem kliniczny. Występuje ona zarówno w nowotworach wczesnych, jak i uogólnionych, w następstwie $m$. in. zespołów złego wchłaniania, paranowotworowych, a także menopauzy lub andropauzy, zarówno fizjologicznej jak i wyindukowanej leczeniem. Szereg badań dotyczy utraty masy kostnej wywołanej stosowaniem m.in. inhibitorów aromatazy, analogów LHRH, antyandrogenów czy kortykosteroidów. Wcześniej wykazano korzyść z profilaktycznego stosowania bisfosfonianów, preparatów wapnia i witaminy D (w grupie wysokiego ryzyka złamań), a także regularnych ćwiczeń fizycznych. W badaniu ABCSG 18 oceniono profilaktyczne działanie denozumabu w grupie chorych na wczesnego raka piersi po menopauzie otrzymujących uzupełniające leczenie inhibitorami aromatazy (abstr. 504). Wykazano, że w porównaniu z placebo denozumab powoduje znamienne obniżenie ryzyka złamań ( $\mathrm{HR}=0,5)$, dłuższy czas do wystąpienia pierwszego złamania oraz poprawę gęstości masy kostnej. Wątpliwości budzi jednak brak informacji o rodzaju stosowanych inhibitorów aromatazy oraz czasu stosowania tych leków, a także niepokojąco wysokie odsetki złamań kostnych w grupie otrzymującej placebo (10\% w ciągu 3 lat; $16 \%-5$ lat i $26 \%$ - 7 lat), które były znacznie wyższe niż w badaniach rejestracyjnych dla inhibitorów aromatazy oraz w metaanalizie EBCTCG.

Kwas zoledronowy jest od kilku lat szeroko stosowany w zapobieganiu przerzutom do kości, niezależnie od lokalizacji i liczby przerzutów. Obecnie jest on zarejestrowany we wszystkich typach nowotworów i podawany rutynowo w postaci dożylnych wlewów co 4 tygodnie. W opublikowanym w 2014 roku badaniu OPTIMIZE-2 wykazano jednak, że równie skuteczne jest podawanie tego leku co 12 tygodni. Badanie CALGB 70604 potwierdza wcześniejsze obserwacje (abstr. 9501). Podawanie co 12 tygodni jest wygodniejsze dla chorych, tańsze i prawdopodobnie mniej toksyczne.

Połączenie aprepitantu z setronami i deksametazonem jest zalecane w zapobieganiu nudności i wymiotom u chorych otrzymujących wysoce emetogenną chemioterapię. Porównanie przeciwwymiotnego działania olanzapiny i fosaprepitantu u chorych poddawanych równoczasowej radiochemioterapii z powodu zaawansowanych nowotworów regionu głowy i szyi wykazało podobną skuteczność obu 
leków w zapobieganiu wymiotom, natomiast w profilaktyce nudności skuteczniejsza okazała się olanzapina (abstr. 9502). Ta pochodna oksazepiny ma działanie neuroleptyczne, wykazuje powinowactwo do receptorów 5HT3, D2, M1, H1 i jest obecnie zarejestrowana w leczeniu zaburzeń psychicznych.

\section{Nowotwory układu moczowego}

Piotr Potemski

U chorych na zaawansowanego raka pęcherza moczowego z progresją po leczeniu cisplatyną możliwości leczenia są bardzo ograniczone. Klasyczne leki cytotoksyczne (winflunina, gemcytabina, ifosfamid, paklitaksel, nab-paklitaksel, docetaksel, pemetreksed) były oceniane w małych grupach chorych. Mediany czasu wolnego od progresji nie przekraczały pół roku; nie stwierdzano także wyraźnego wydłużenia czasu przeżycia. Aktywność leków anty-PD1 w tej grupie chorych jest obiecująca, toksyczność umiarkowana, a ekspresja PD-L1 w komórkach guza oraz naciekających limfocytach może być czynnikiem predykcyjnym (abstr. 4501 - badanie fazy la z atezolizumabem; abstr. 4502 badanie fazy lb z pebrolizumabem). Trwające badania III fazy zweryfikują te obserwacje. Znana od lat 1990 erybulina jest pochodną halichondryny B, substancji uzyskanej w 1986 roku z gąbki Halichondria okadai, hamującą aktywność mikrotubul.W 2010 uzyskała rejestrację FDA u chorych na raka piersi, a w 2015 wykazano wydłużenie mediany całkowitego przeżycia pod wpływem skojarzenia tego leku z dakarbazyną u chorych na mięsaki tkanek miękkich. W badaniu II fazy u chorych na zaawansowanego raka pęcherza z komórek przejściowych uzyskano wprawdzie zadowalające odsetki odpowiedzi (27-30\%), ale parametry przeżycia w grupie wcześniej leczonych nie odbiegają od znanych z piśmiennictwa (abstr. 4504).

Lenwatynib to nowy wielokinazowy inhibitor VEGFR1-3, FGFR1-4, PDGFRa, KIT i RET, zarejestrowany przez FDA w lutym 2015 u chorych na opornego na jod promieniotwórczy zróżnicowanego raka tarczycy. W badaniu II fazy u chorych na jasnokomórkowego raka nerki z progresją po jednej linii leczenia anty-VEGF zastosowanie lenwatynibu w skojarzeniu z ewerolimusem było istotnie skuteczniejsze od monoterapii ewerolimusem w zakresie odsetka obiektywnych odpowiedzi, przeżycia wolnego od progresji i całkowitego (abstr. 4506). Toksyczność terapii dwulekowej była większa, ale akceptowalna, a badania III fazy są w toku.

W prospektywnym badaniu u chorych na uogólnionego lub miejscowo zaawansowanego raka gruczołu krokowego o dużym ryzyku nawrotu oceniono wpływ docetakselu i/lub kwasu zoledronowego, dołączonych do hormonoterapii pierwszej linii na czas całkowitego przeżycia (abstr. 5001). Dodanie docetakselu wpłynęło na poprawę wyników leczenia, natomiast dodanie kwasu zoledronowego nie miało wpływu na wyniki. Dyskusja na temat wartości docetakselu zastosowanego w takim wskazaniu toczy się od kilku lat, a wyniki 3 przeprowadzonych w ostatnim czasie badań są sprzeczne. Dołączenie docetakselu do hormonoterapii można rozważyć u chorych z nowo rozpoznanym przerzutowym rakiem gruczołu krokowego i u wybranych chorych z miejscowo zaawansowanym nowotworem o dużym ryzyku wznowy. Ewentualna zmiana standardu wymaga jednak dłuższej obserwacji chorych.

Uzupełniające leczenie docetakselem u leczonych radykalnie chorych z dużym ryzykiem wznowy budzi wątpliwości (abstr. 5002). U chorych z progresją podczas leczenia enzalutamidem lub abirateronem często ujawnia się rak o pośredniej atypii, cechujący się złym rokowaniem (abstr. 5003).

\section{Rak piersi}

Aleksandra Łacko

Upowszechnienie programów badań przesiewowych powoduje wzrastającą liczbę rozpoznań przewodowego raka nienaciekającego (ductal carcinoma in situ, DCIS). Standardem leczenia tych chorych pozostaje zabieg oszczędzający uzupełniony radioterapią lub amputacja. Dołączenie tamoksyfenu zmniejsza o 32\% ryzyko nawrotu miejscowego i o $53 \%$ ryzyko raka drugiej piersi. Wiele chorych leczonych jest jednak nadmiernie, bowiem u 40-85\% chorych na DCIS o wysokim zróżnicowaniu nie dojdzie do nawrotu. Problemem pozostaje identyfikacja chorych o wysokim ryzyku nawrotu. W badaniu NSABP B-35 porównano uzupełniające leczenie anastrozolem z leczeniem tamoksyfenem u chorych po menopauzie i przebytym leczeniu miejscowym. Wykazano bardzo dobre wskaźniki przeżycia niezależnie od rodzaju hormonoterapii (abstr. LBA 500). Anastrozol był bardziej skuteczny w odniesieniu do czasu wolnego od raka piersi, szczególnie w grupie kobiet młodszych ( $<60$ lat), ale bez wydłużenia czasu całkowitego przeżycia. Anastrozol może być rozważany jako alternatywa dla tamoksyfenu u chorych na DCIS po menopauzie, a wybór leku powinien uwzględniać indywidualną sytuację kliniczną.

Wzrost raków piersi z ekspresją ER i/lub PgR zależy od cykliny D1, która aktywując zależne od niej kinazy (CDK4/6), umożliwia przejście komórek nowotworowych z fazy G1/S cyklu komórkowego do fazy podziału. W badaniu III fazy PALOMA3 wykazano, że palbocyklib, doustny inhibitor CDK4/6, hamujący proliferację $w$ liniach komórkowych, dołączony do fulwestrantu powoduje znamienne wydłużenie mediany czasu wolnego od progresji w porównaniu z fulwestrantem z placebo u chorych na luminalnego raka piersi (abstr. LBA 502). Korzyść ta nie przekłada się jednak na wydłużenie czasu przeżycia.

W leczeniu uzupełniającym HER2-dodatniego raka piersi standardem jest podawanie trastuzumabu przez rok. Wy- 
dłużenie tego leczenia poprzez stosowanie neratynibu, doustnego inhibitora kinazy tyrozynowej nowej generacji blokującego sygnał z receptorów rodziny HER, przez kolejny rok poprawia czas przeżycia wolny od inwazyjnego nawrotu (IDFS), ale krótki czas obserwacji nie pozwala na ocenę jego wpływu na czas przeżycia (abstr. 508). Problemem pozostaje również tolerancja, bowiem u $40 \%$ chorych obserwowano biegunkę w 3. stopniu, co może być związane z nieodwracalnym działaniem neratynibu.

Potrójnie ujemny rak piersi jest chorobą niejednorodną. U części chorych występuje ekspresja receptora androgenowego, co uzasadnia próby leczenia enzalutamidem (abstr. 1003). W badaniu II fazy wyniki są zachęcające, a badania III fazy są w toku.

\section{MISCELLANEA}

Barbara Radecka

Przedmiotem ostatniego wykładu tegorocznego "Spotkania..." były głównie zagadnienia związane z leczeniem dzieci i osób starszych. W sesji plenarnej kongresu ASCO 2015 zaprezentowano losy niemal 35 tys. ozdrowieńców leczonych w latach 1970-1999 z powodu choroby nowotworowej rozpoznanej przed 21 r.ż. Przedmiotem analizy była umieralność związana z późnymi efektami leczenia onkologicznego (niezależna od nawrotu choroby i przyczyn zewnętrznych). W długoletniej obserwacji wykazano stopniowe zmniejszanie się 15-letniego skumulowanego ryzyka zgonu z powodu chorób serca, płuc oraz wtórnych nowotworów u osób leczonych z powodu ostrej białaczki limfatycznej, chłoniaka Hodgkina i guza Wilmsa. Ma to związek z obserwowaną w ciągu ostatnich 3 dekad mniejszą agresywnością leczenia oraz wcześniejszym wykrywaniem późnych powikłań.

Coraz większym wyzwaniem staje się leczenie onkologiczne osób w podeszłym wieku, nie tylko z powodu wzrostu liczebności tej populacji, ale przede wszystkim z powodu obecności współistniejących chorób związanych z wiekiem. $\mathrm{U}$ chorych w podeszłym wieku z obniżonym wskaźnikiem klirensu kreatyniny, obliczanym na podstawie aktualnej masy ciała, ryzyko powikłań (hematologicznych i niehematologicznych) było wyższe. Obniżenie filtracji o $10 \mathrm{ml} / \mathrm{min}$ zwiększało ryzyko o $12 \%$ i dotyczyło to zastosowania nie tyko leków nefrotoksycznych (abstr. 9509). Stężenie kreaty- niny w surowicy krwi nie miało znaczenia predykcyjnego dla toksyczności.

Oceniono wpływ wieku chorych ( $<70$ vs $\geq 70$ lat) na wyniki radioterapii lub radiochemioterapii w połączonej analizie danych z 3 badań z randomizacją (RTOG 9003, RTOG 0129 i RTOG 0522) u chorych na miejscowo zaawansowane nowotwory głowy i szyi (abstr. 6003). Udział chorych w wieku powyżej 70 lat w badaniach klinicznych był niższy w porównaniu z przeciętną populacją tej grupy chorych. Czas przeżycia starszych chorych był krótszy niezależnie od palenia tytoniu oraz ekspresji białka p16, szczególnie w przypadku leczenia skojarzonego oraz stosowania chemioterapii zawierającej cisplatynę.

Zgodnie z wynikami badania CALGB 9343, znanymi od 2004 roku, u chorych na wczesnego (pT1N0) raka piersi z ekspresją ER w wieku powyżej 70 lat poddanych zabiegowi oszczędzającemu dołączenie do tamoksyfenu uzupełniającej radioterapii nie poprawia wyników leczenia. Wykorzystując dane epidemiologiczne z bazy SEER (Surveillance, Epidemiology, and Results Program), oceniono retrospektywnie codzienną praktykę w zakresie zastosowania radioterapii $w$ tej populacji chorych (abstr. 573). Potwierdzono dane z badania CALGB 9343 oraz wykazano, że na przestrzeni lat (dane z 1990, 2005 i 2010) maleje odsetek chorych poddanych amputacji piersi (odpowiednio 74,2\%, 27,4\% i 25\%). Towarzyszy temu wzrost udziału zabiegów oszczędzających skojarzonych z radioterapią (odpowiednio 21,1\%, 51,5\% i 52,7\%), aczkolwiek odsetek chorych leczonych bez radioterapii jest nadal względnie niski (odpowiednio 4,7\%, 21,1\% i 22,4\%).

W ostatnich 2 dekadach u chorych na raka piersi obserwuje się poprawę przeżyć zależnych od choroby zasadniczej, co jest wynikiem postępu we wczesnym wykrywaniu i leczeniu. W retrospektywnym badaniu kohortowym wykazano jednak, że nie odnosi się to do starszych chorych (powyżej 70 lat; abstr. 1010). Poprawy należy upatrywać w objęciu tej grupy wiekowej badaniami przesiewowymi oraz w optymalizacji leczenia raka piersi w zaawansowanych stopniach.

Wszystkie wykłady "Spotkania po ASCO 2015" dostępne są w wersji wirtualnej na stronie www.poasco.pl. Kolejne, XV spotkanie odbędzie się w Gdańsku w dniach 1-2 lipca 2016 r.

\section{Dr n. med. Barbara Radecka}

Opolskie Centrum Onkologii

ul. Katowicka 66a, 45-060 Opole

e-mail:brad@onkologia.opole.pl 